\title{
PERBUATAN MANUSIA DALAM PANDANGAN HADIS TELAAH PEMIKIRAN HADIS DALAM PANDANGAN MUHAMMAD Al-GHAZALI
}

\author{
M Khoirul Hadi al Asy'ari dan Ali Hasan Siswanto \\ Fakultas Syariah IAIN Jember dan Fakultas Tarbiyah dan Ilmu Keguruan IAIN Jember \\ arimoh16@gmail.com
}

Diterima 1 Juni 2019 | Direview 15 Juni 2019 | Diterbitkan 27 Juni 2019

\begin{abstract}
:
This study is a research-based research is research library which starts from understanding the traditions relating to buman actions, in this case the actions of people who exist in the understanding of the traditions of the prophet were analyzed using Matan pendektan and critical theory ala Muhammad al-Ghazalii, the da two important questions in this study, the first of how the views of Mubammad al-Ghazali against the traditions of the buman actions in relation to understanding jabariyyah and Qadariyyah, both how the biography of the life of Muhammad al-Ghazali al.hasil of this study is, first that Muhammad al-Ghazali criticized traditions of human actions according to the Jabriyyah and feed space impartial understanding with a view Qadiriyyah. Both figures dalah know boigrafi Muhammad al-Ghazali, sebgai contemporary thinkers capable hadith in Muslim world.
\end{abstract}

Keywords: Perbuatan, Muhammad al-Ghazali, Jabariyyah, dan Qadariyyah

\begin{abstract}
Abstrak:
Penelitian ini adalah penelitian berbasis library research yang bertitik tolak dari memahami hadis yang berkenaan dengan perbuatan manusia, dalam hal ini perbuatan manusia yang ada dalam pemahaman hadishadis nabi dianalisis dengan menggunakan pendekatan dan teori kritik matan ala Muhammad al-Ghazali al-, maka da dua pertanyaan penting dalam penelitian ini, pertama bagaimana pandangan Muhammad al-Ghazali terhadap hadis-hadis perbuatan manusia dalam kaitannya dengan paham Jabariyyah dan Qadariyyah, kedua bagaimana biografi kehidupan Muhammad al-Ghazali. hasil dari penelitian ini adalah, pertama bahwa Muhammad al-Ghazali mengkritik hadis-hadis perbuatan manusia menurut kalangan Jabariyyah dan memberikan ruang pemahaman yang berimbang dengan pandangan Qadariyyah. Kedua adalah mengetahui biografi tokoh Muhammad al-Ghazali, sebagai pemikir hadis kontemporer yang mumpuni di dunia muslim.

Kata Kunci: Perbuatan, Muhammad al-Ghazali, Jabariyyah, dan Qadariyyah.
\end{abstract}

\section{Pendahuluan}

Dalam pemikiran Islam dikenal suatu paham Jabariyyah dan Qadariyah yang memandang manusia tidak merdeka, otonom dalam mengerjakan perbuatannya, dalam istilah inggrisnya paham itu disebut dengan paham fatalisme, detirminasi, atau presdestinasi, jahm. ${ }^{1}$ Penyebar pertama ajaran ini, memandang Manusia tidak mempunyai daya, kekuasaan, kemaunnya dan pilihan untuk berbuat sesuatu. Manusia berbuat secara terpaksa dan Tuhan adalah pencipta tindakannya, manusia tak ubahnya seperti benda-benda lain, misalnya pohon berbuah, yang menciptakan buah adalah Allah, bukan pohon itu sendiri, seperti halnya perbuatan pahala dan siksaan adalah paksaan, kalau demikian, maka kewajiban juga paksaan $(J a b r)^{2}$ manusia tak ubahnya seperti bulu burung yang di tiup oleh angin. Bulu itu bergerak atau diam ditentukan oleh ada atau tidak adanya angin. ${ }^{3}$

Jalaludin Rahmat berpendapat bahwa paham Jabariyyah dalam Islam ini berkelanjutan pada aliran asyariyyah, ${ }^{4}$ paham ini memandang manusia lemah. Manusia yang seperti itu bergantung kepada kehendak dan kemauan Tuhan. Atas dasar ini Harun Nasution menyatakan bahwa paham ini lebih dekat dengan Jabariyyah, dalam menggambarkan

\footnotetext{
${ }^{1}$ Jahm Bin Safwan adalah warga Khurasan (Iran) ia sebagai Menteri (Wazir) al-Haris Bin Surayj. Keduanya memberontak kepada penguasa Dinasti Umawi sehingga keduanya di bunuh pada tahun $128 \mathrm{H}$. Lihat Ahmad Amin, Fajr Islam (Kairo: Al-Nahdah al-Misriyyah,1975), h. 286-87.

${ }^{2}$ Muhammad Abbad al-Karim al-Syahratanni, Al-Milal wa al-Nihal, Juz I (Beirut: Dar al-fikr, t,t) 87.

${ }^{3}$ Ahmad Amin, Farl Islam, h. 286.

${ }_{4}^{4}$ Jalaludin Rahman, Konsep Perbuatan Manusia Menurut Al-Qur'an, Suatu Kajian Tafsir Tematik. (Jakarta: Bulan Bintang,1992), h. 86.
} 
hubungan perbuatan manusia dengan kehendak dan kekuasaan Tuhan al-Asyari memakai istilah Kasb (perolehan). ${ }^{5}$ Paham ini ternyata mempunyai dukungan naqliyah dan hadis dalam Islam sehingga membuat kalangan Jabariyyah semakin fanatik, dalam kajian hadis sering disebut dengan kajian hadis fatalistik, hadis ini disebut fatalistik karena dalam secara ekplisit hadis ini mengejarkan pemhaman sikap yang fatalistik. Karena secara tektual memang mengajarkan perilaku yang fatalistik.

Sedangkan lawan dari kalangan Jabariyyah adalah kalangan Qadariyyah, kalangan ini adalah kalangan yang timbul akibat pemikiran golongan Jabariyyah yang di bawa oleh Bani Umayyah, pemahaman ini menyatakan bahwa Allah Tidak mendetarminasi apa yang manusia lakukan: Manusia bebas dan bisa memilih antara yang benar dan yang salah. Hal ini sangat bertentangan dengan kepentingan Bani Umayyah. Pendapat Qadariyyah ini secara tidak langsung bahwa melawan, dan merubah, Status Qua adalah satu hal yang mungkin dilakukan, pandangan yang radikal ini mempunyai dukungan dengan adanya militansi Khawarij.

Apalagi dengan munculnya hadis atau maqalah ulama yang pada waktu itu memojokkan kalangan Qadariyyah hadis tersebut berbunyi:

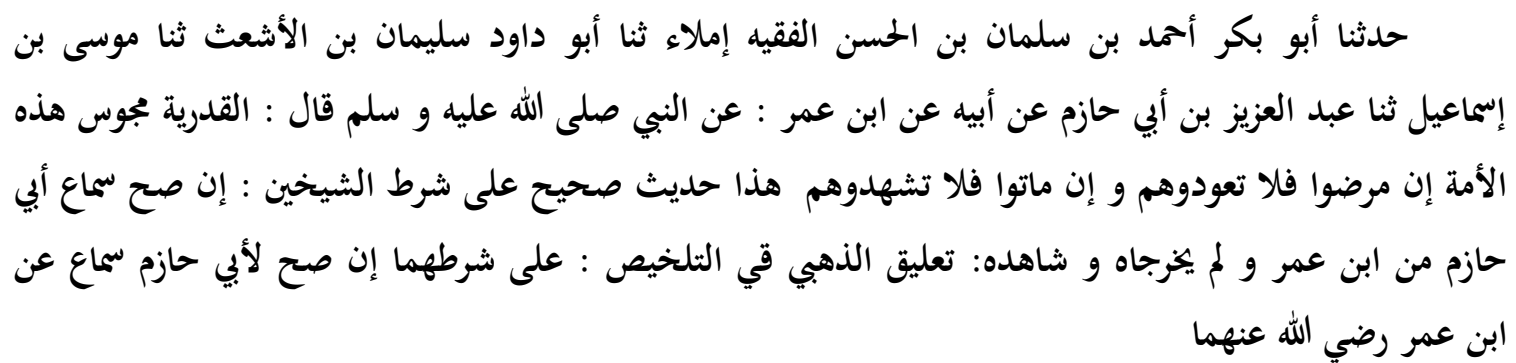

Artinya: "Al-Qadariyyah adalah Majusinya umat (Islam) ini. Jika mereka sakit jangan dijenguk. Jika mereka mati jangan disaksikan" (HR. Sunan Abu Daud, Sunan Baihaqi).

Dua aliran ini sangat bertolak belakang dan tetapi keduanya mempunyai dua pendekatan dan pemahaman hadis dalam hal ini khusus terhadap hadis-hadis yang berkaitan dengan perbuatan Manusia. Jika Jabariyyah menggunakan hadis yang bersifat fatalistik begitu pula kalangan Qadariyyah menggunakan hadis-hadis yang menguatkan argument dan pendapat mereka, artikel ini mencoba menjawab bagaimana perbuatan manusia dalam pandangan hadis, sebenarnya bagaimana mengetahui pandanngan yang benar terhadap hadis-hadis yang membahas perbuatan manusia, berdasarkan perspektif teori pemahaman hadis seorang ulama Hadis Kontemporer yaitu Muhammad al-Ghazali, sehingga penulis dapat mereview dan mengomentari pandangan ulama ini dalam kontek teori pemahaman hadis. Penulis pada akhirnya akan melakukan kejadian pemahaman hadis, mungkin hanya sebuah respons yang sifatnya komplemental terhadap apa yang telah dilakukan oleh Muhammad al-Ghazali.

\section{Biografi Muhammad Al-Ghazali}

Muhammad al-Ghazali lahir pada tahun 1917 di Nakla al-Inab, sebua desa kecil yang terkenal di Mesir yang banyak melahirkan tokoh-tokoh Islam terkemuka pada zamannya,

${ }^{5}$ Harun Nasution, Teologi Islam, Aliaran-Aliran, Sejarab Analisis Perbandingan. (Jakarta: Yayasan Penerbit Universitas Indonesia1978), h. 106.

${ }^{6}$ Abdullah Saeed, Pemikiran Islam Sebuah Pengantar. (Yogyakarta: Baitul Hikmah Press, 2014), h.12

${ }^{7}$ Az-Zahabi, Al-Mustadrak. h. 117. 
tokoh-tokoh tersebut pada zamannya. Tokoh tokoh tersebut diantaranya adalah Muhammad Abduh, Hasan al-Banna, Mahmud Syaltut dan lain sebagainya. ${ }^{8}$

Ayahandanya memberikan nama Muhammad al-Ghazali, karena ia telah bermimpi memperoleh isyarat dari Hujjah al-Islam, Abu Hamid al-Ghazali agar mencantumkan nama Imam al-Ghazali pada anaknya tersebut. ${ }^{9}$ Muhammad al-Ghazali adalah pengagum Imam alGhazali dan Ibnu Taimiyyah, dia mengatakan seperti yang telah dikutip oleh Munawar alZahidi, "bila Imam al-Ghazali mempunyai otak ahli filsafat dan Ibnu Taimiyyah otak ahli fiqh, maka saya mengangap diri saya adalah murid dari kedua tokoh tersebut dalam bidang filsafat dan ilmu Figh. ${ }^{10}$ Ide-ide al-Ghazali (baca Muhamamad al-Ghazali) yang dasar pemikiran berangkat dari al-Qur'an dan hadis sangat syarat dengan objektifitas dengan kajian yang sangat ilmiah dan profesionalitas. Dia bersikap hati-hati dan sangat tidak seenaknya dalam mengeleminasi pendapat para ulama pendahulunya atau ulama yang semasanya. Dia adalah pemikir Islam yang berpikrian maju dan berpikiran terbuka terhadap pikiran-pikiran Agama. ${ }^{11}$

Muhammad al-Ghazali memlalui pendidikan di tempat khusus yaitu tempat menghafal al-Quran, di tempat inilah dia mampu menghafal al-Quran selesai sampai 30 Juz dalam usia yang relatif muda yaitu sepuluh tahun. Setelah menyelesaikan pendidikan menegah atasnya, pada tahun 1937, dia melanjutkan kuliah di fakultas ushuludin Universitas al-Azhar di Kairo, dan mendapatkan gelar sarjana di Kairo dan mendapat gelar di sarjana di tahun 1941. Dan pada tahun 1943 memperoleh gelar master di program Fakultas Bahasa Arab. ${ }^{12}$ Pada saat itu Muhammad al-Ghazali masih berumur 26 tahun, namun dia sering sekali melakukan dakwah di masjid-masjid di Kairo, dan pada saat belajar di Kairo dia bertemu dengan beberapa guru yang sangat terinpirasi dengan dan menginpirasi dalam kehidupannya, Syaikh abdul Aziz alBilal, dan dan syeikh Ibrabim al-Ghorbawi, Syaikh Abdul Azhim az-Zarqani, Syaikh Mubammad Syaltut, Syaikh Muhammad Abu Zabroh dan Dr Muhammad Yusuf Musa, dan ulama-ulama Mesir lainya. ${ }^{13}$ Dari para guru-gurunya tersebut integritasnya terbentuk, tetapi dari sekian guru yang ia ta'dimi adalah seorang tokoh terkemuka Hasan al-Banna ${ }^{14} \mathrm{Al}$-Ghazali seorang tokoh dan pemikir yang mengabadikan diri pada dunia pendidikan dan dakwah, sampai akhir hidupnya dia masih tercatat sebgai seorang da'i dan pendidik yang tidak bosan-bosannya menyampaikan apapun yang dirasanya kurang sejalan dengan hati nuraninya. Kiprah dan dalam dunia pendidikan dan dakwah mempunyai pengaruh dalam dunia muslim dan khususnya daerah Timur Tengah, baik mesir, Arab Saudi, Libanon, maupun al-Jazair. Diceritakan oleh Yusuf al-Qardawi bahwa buku-buku yang dikarang oleh Muhammad alGhazali laku keras di kalangan banyak pemuda dan mereka mengulang dan menghafal katakata Muhammad al-Ghazali. Salah satu ulama dan pejabat yang mengikuti kuliah di al-Azhar pada tahun 1950, menghafal di luar kepala Muqaddimah dalam karya Muhammad al-Ghazali al-Islam wa alauda al-Iqtishadiyyah. ${ }^{15}$

${ }^{8}$ Syaikh Muhammad al-Ghazali, "Dai yang Menulis" terjemahan, dan suntingan Thalib anis dalam Syeikh Muhammad al-Ghazali, Berdialog dengan Al-Qur'an Memahami Pesan Kitab Suci dalam Kebidupan Masa Kini, penerjemah, Maskur Hakim dan Ubaidillah, penyunting, T halib Anis (Bandung: Mizan,1996), h. 5.

${ }^{9}$ Syeikh Muhammad al-Ghazali, Analisis Polemik Hadis Tranformasi Modernisme, terjemahan, Muh Munawir alZahidi. (Surabaya: Dunia Ilmu, 1997), h. V.

${ }^{10}$ Ibid.

${ }^{11}$ Ibid, h. 9.

${ }^{12}$ Muhammad al-Gazali, h. 5-6.

${ }^{13}$ Sirah Hayah.

${ }^{14}$ Beliau adalah pendiri dari gerakan Islam Ikhwanul al-Muslimun Lahir pada tanggal 1906 di desa alMahmudiyyah, salah satu desa di wilayah al-buhaiwirioh di mesir. Dia dibesarkan dalam kelurga yang pengarang dan Ulama as-Sunnah al-Muthaharah, sejak kecil Imam hasan al-Banna di didik dalam rumah tangga yang mempunyai perpustakaan yang lengkap dia di bombing langsung oleh ayahnya dan dan berteman dengan syikh zahran, yang pada akhirnya menjadi tokoh tyang besar di Mesir, Lihat Ali Abdul Halim Mahmaud, Ikhwanul al-Muslimun, terjemahan Syafril. (Jakarta: Gema Insani Press, 1997) h. 22-23.

${ }^{15}$ Yusuf al-Qardhawi, al-Syaikh al-Ghazali Kama araftuhu, h. 21. 
Pasca lulus dari Universitas al-Azhar, Muhammad al-Ghazali menekuni dunia dakwah dan pendidikan, kedua bidang tersebut yang mengantarkan Muhammad al-Ghazali menjadi orang yang mashur baik dalam level internasional dan nasional. Pada dasarnya Muhammad al-Ghazali adalah ulama yang aktif dalam berdakwah, baik lewat tulisan maupun lisan, selama hidupnya dia menulis hampir sampai lima puluh empat buku. Dia juga sering menghadiri muktamar dan pertemuan ilmiah di berbagai dunia dan Negara, dia sering muncul di televisi, radio dan surat kabar terkemuka. ${ }^{16}$ Awal mula al-Ghazali berkecimpung dalam dunia dakwah, dia ditunjuk sebagai seorang Imam dan Khatib pada masjid al-Utba al-Khadra Kairo, pada tahun 1943. Di Saudi Arabia dia memberikan cerakah-ceramah keagamaan melalui radio, televisi, dan menulis di berbagai majalah dan surat kabar. Muhamamad al-Ghazali juga sering menjadi pembicara di negara-negara muslim dan non muslim di Amerika maupun Eropa. ${ }^{17}$

Kekuatan kata dan keindahan diksi yang digunakan oleh Muhamamad al-Ghazali dalam berbicara dan membuat pengajian, kuliah maupun seminar yang dihadiri oleh alGhazali selalu dipenuhi oleh peserta. Dan hal ini juga diakui oleh Quraish Shihab tatkala mengikuti kuliah bersama al-Ghazali. Dia menuliskan :

Sewaktu mengajar di fakultas Ushuludin, Universitas al-

Azhar Mesir, saya melibat dan mengalami betapa kuliah-

kuliahnya digemari oleh banyak kalangan mahasiswa,

sehingga, seringkali, kursi-kursi kami di duduki oleh

mahasiswa fakultas lain di lingkungan al-Azhar, yang

seharusnya mengikuti kuliah di tempat masing-masing. ${ }^{18}$

Keunggulan dalam bidang orator tidak membuat Muhammad al-Ghazali menjadi seorang yang ekslusif, sedangkan dalam bidang pendidikan dedikasi Muhammad al-Ghazali sangatlah tinggi, di almamaternya, Universitas al-Azhar. Muhammad al-Ghazali mengajar di Fakultas Syariah, Ushuludin, Dirasah al-Arabiyyah wa al-Islamiyyah. Dan Fakultas Tarbiyah. Dia juga penulis yang aktif di berbagai surat kabar dan majalah al-Azhar. ${ }^{19}$ Selain mendapat gelar Guru besar di al-Azhar dia juga aktif dalam penelitian yang berbasis beda agama, dakwah, dan tema-tema sosial. di adalah salah satu ketua dewan akademik pada Institut Internasional Pemikiran Islam (Chairmen of the academic council of the internasional institute of islmaic thaough).

Memang sejak awal dia adalah anggota kelompok Ikhwanul al-Muslimun, walupun demikian pandanngannya sangat objektif sekali berkaitan dengan kebenaran yang di bela, ia sangat benci dengan adanya penyimpangan dan segala sesuatu yang menyimpang dari Islam, ${ }^{20}$ ia menyatakan bahwa kepentingan Islam adalah diatas segala-galanya, seandainya kepentingan al-Ikwanu al-Muslimun adalah melakukan penyimpangan dengan kepentingan Islam, maka kepentingan Islam harus diutamakan dan kepentingan al-Ikwan al-Muslimun harus di buang jauh-jauh. ${ }^{21}$ Pada hari Sabtu tanggal Syawal $1416 \mathrm{H}$ bertepatan dengan tanggal 6 Maret 1996, Muhammad al-Ghazali berpulang ke rahmatullah. Ia meninggal ketika sedang berada di Riyad, Saudi Arabia untuk menghadiri sebuah seminar, jenazahnya di

\footnotetext{
${ }^{16}$ Lihat, Fathi Hasan Malakawi, h. 227.

${ }^{17}$ Suryadi, Metode Hadis Nabi Telah atas Pemikiran Mubamamd al-Ghazali dan Yusuf al-Qardhawi, Disertasi, Yogyakarta: UIN Sunan Kalijaga, 2004, h. 25-26.

18Muhamamad Quraish Shihab, "Kata Pengantar" dalam Muhammad al-Ghazali, Studi Kritis atas Hadis Nabi SAW, antara pemahaman tektual dan kontektual, terjemhana Muhammad al-Baqir. (Bandung: al-Mizan, 1993), h. 7.

${ }^{19}$ Zuhairi Misrawi, Al-Az̧ar Menara Ilmu, Reformasi, dan Kiblat Keulamaan. (Jakarta: Kompas, 2010), h. 214.

${ }^{20} \mathrm{Al}-\mathrm{Ikwanu}$ al-Muslimun, artinya persaudaran kaum muslimin, adalah organisasi yang didirikan bertujuan melaksanakan perintah agama yang hakiki, menjelaskan pesan al-Qur'an dan keyakinan Islam yang benar, oragnisasi ini didirikan pada tahun 1928 tepatnya pada bulan Maret, di Ismailiyyah Negara mesir, oleh Hasan al-banna (1906-1949) informasi lebih lengkap bisa di lihat di Ishak Mussa al-Husaini, Ikhwan al-Muslimun. (Jakarta: Grafiti Pers, 1983), h. 3-93.

${ }^{21}$ Syeik Muhammad al-Ghazali, Dai yang.., h. 6.
} 
makamkan di pekuburan Baqi hanya beberapa meter saja dengan makam Rasulullah saw, makamnya persis di antara makam Imam Malik dengan Imam Nafi'. ${ }^{22}$

\section{Hadis-Hadis Perbuatan Manusia dalam Pandangan Jabariyah (Fatalistik)}

Dalam literatur-literatur hadis, kita bisa menemukan banyak hadis tentang fatalisme, namun dalam tulisan ini akan di ambil hanya empat hadis saja sebagai sample, dan selebihnya adalah hadis-hadis dalam pandangan Qadariyyah, pertama, dalam pandangan Muhammad al-Ghazali terhadap pandangan Hadis-hadis yang bersifat fatalistik itu ternyata termasuk dalam katagori hadis-hadis yang shahih sanadnya. Adapun yang pertama dari empat hadis fatalistik itu diriwayatkan oleh Tirmizhi dari Umar Bin Khatab, r.a yang beritanya seperti berikut:

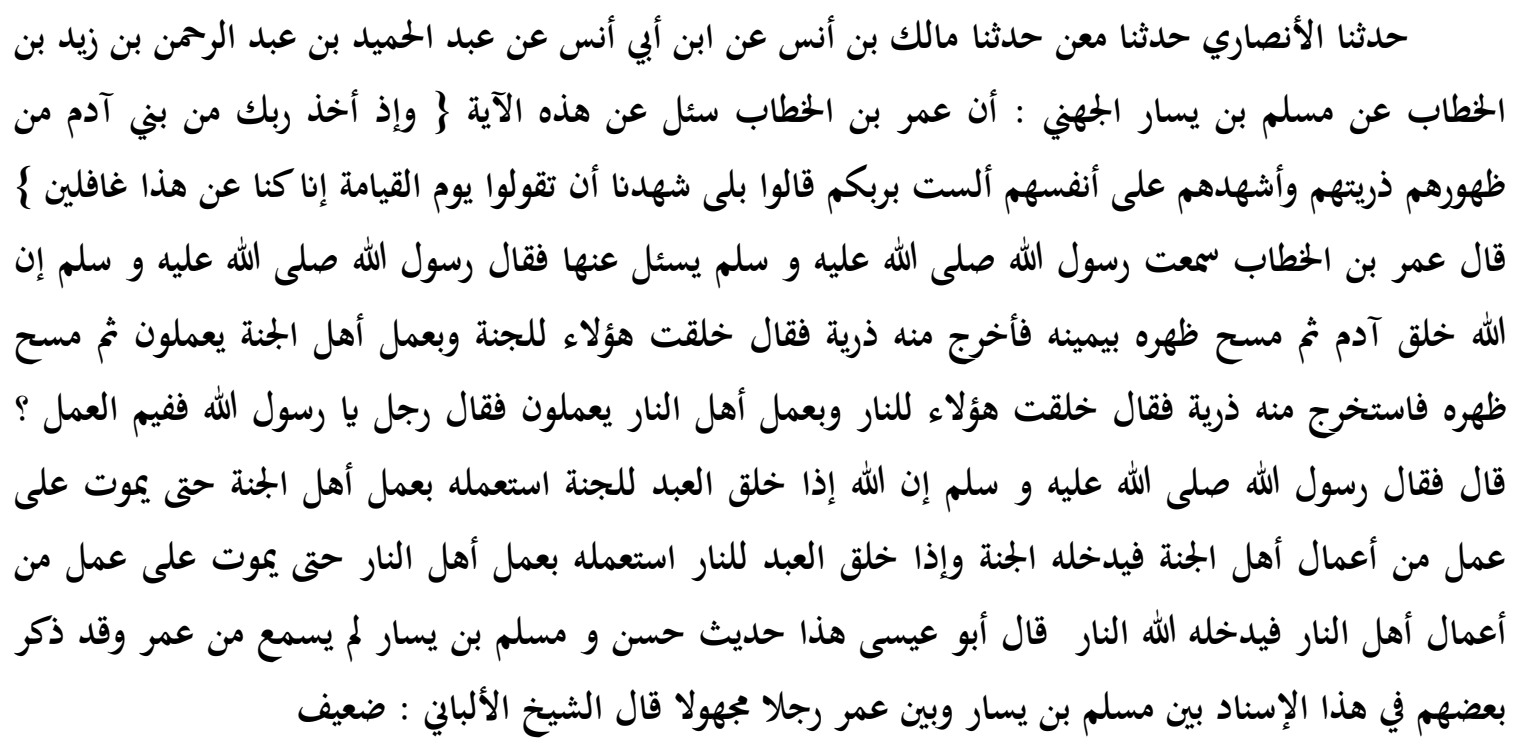

Artinya: "Bahwa ia pernah di tanya tentang makna firman Allab SWT, ...'Dan (Ingatlah) ketika Tuban mengeluarkan keturunan anak-anak. Adam dari sulbi mereka dan Allah mengambil kesaksian terhadap diri-diri mereka sendiri, "Buakankah aku ini Tuhanmu?" Mereka menjawab: "ya dan kami bersaksi", Yang demikian itu, agar Hari Kiamat, Kamu Kamu tidak akan mengatakan: "Sesungguhnya Kami Lengah (Tidak. Tabu) akan hal itu, (Al-A'raf: 172), Kata Umar Bin khatab selanjutnya: Telah Ku dengar Rasulullah saw, -ketika ditanya tentangnya- Bersabda: "Sesunggubnya Allah menciptakan Adam lalu mengusap punggungnya dan tangan kananNya, dan mengeluarkan sejumblah anak keturuan darinya, seraya berkata: "Mereka ini kucipta untuk Surga" dan karenanya mereak akan mengerjakan amalan abli surga". Kemudian Allab mengusap sekali lagi punggung Nabi Adam dan dan mengElurakan sejublab anak keturunannya. Seraya berkata "Mereka ini kucipta untuk neraka, dan mereka akan mengerjakan amalan neraka'. Mendengar keterangan Nabi saw, seorang lakilaki berkata: 'untuk apa kita beramal' ya Rasulullah, untuk apa kita beramal ? Jawab Beliau: "Sesungguhnya Allah mencipta Hanba-Nya untuk surga, ia akan menjadikannya mengerjakan amalan abli Surga sampai ia meninggal dunia dalam sesuatu mengerjakan amalan abli Surga, dan ketika ia menciptakan Hamban-Nya untuk neraka, maka ia akan menjadikannya mengerjakan amalan Neraka sampai meninggal dunia dalam keadaan menegrjakan amalan abli neraka, dan Allah akan memasukekan Abli Neraka”.(HR At-Tirmizhi,).

Hadis ini juga di gunakan oleh kalangan Jabariyyah atau dalam pembahasan hadis juga termasuk dalam hadis yang bersifat fatalistik, jika kita mengungkapkan pendapat al-Banni

${ }^{22}$ Syeik Muhammad al-Ghazali, Di Mata..., h. 2. 
dalam hadis ini hadis ini memang tergolong pada wilahay hadis dhaif, sehingga Muhammad al-Ghazali juga menyatakan bahwa hadis ini memng sanad kuat tetapi memiliki matan yang tidak rasional, jika kita merujuk kedalam beberpa syarah hadih klasik maka di daiamnya juga menyatakan perbedaan pendapat, jika kita mengutip pendapat Ibnu Taimiyyah bahwa pemaknaan dengan konsep literalis itu adalah pendapat kelompok ahlu sunnah wal Jama'ah, bahwa Allah menyatakan semua yang diciptaan oleh Allah adalah yang menjadikan sesuatu yang di kuasainya. Jika melihat komentar tersebut memang kalangan klasik masih bertumpu pada kajian sanad sebagaimana di jelaskan secara detail oleh Muhammad Al-Ghazali.

Sedangkan hadis yang kedua adalah hadis yang diriwayatkan oleh Aisyah ra, berikut ini

حدثنا أبو بكر بن أبي شيبة حدثنا وكيع عن طلحة بن ييى عن عمثه عن عائشة بنت طلحة عن عائشة أم

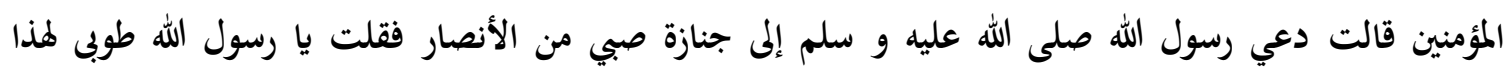

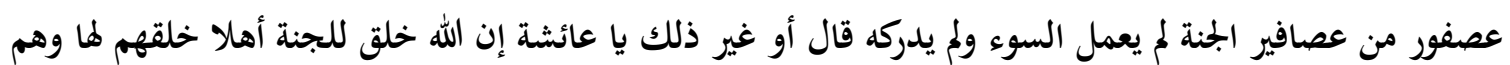

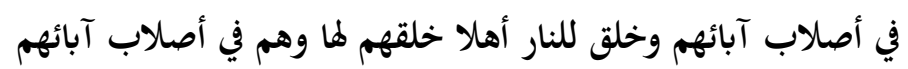

Artinya: "Rasulullah pernah di Undang untuk menyembahyangi jenazah seorang remaja dari kalangan anshar, maka akupun berkata kepda beliau: 'Ya Rasulullah, alangkah bahagianya anak itu! bagiakan seokor burng yang belum mengetahui tentang kejahatan dan belum terlibat dengan sesuatupun!', mendengar itu, Beliau berkata: Atau Mungkin tidak sedemikian itu, hai Aisyah? Sesunggubnya Allah telah mencipta, bagi surge, sejumblah orang-orang yang menjadi penghuninya, mereka diciptakan sejak mereka masih ada di sulbi ayah-ayahnya mereka, Allah juga mencipta, bagi neraka, sejumblah orangorang yang akan menjadi penghuninya, Ia menciptakan mereka untuknya sejak mereka masih dalam sulbi ayah-ayah mereka" .(HR Shahih Muslim). ${ }^{23}$

Adapun hadis yang ketiga adalah hadis yang diutarakan dari Sabl bin Saad yang merawikan :

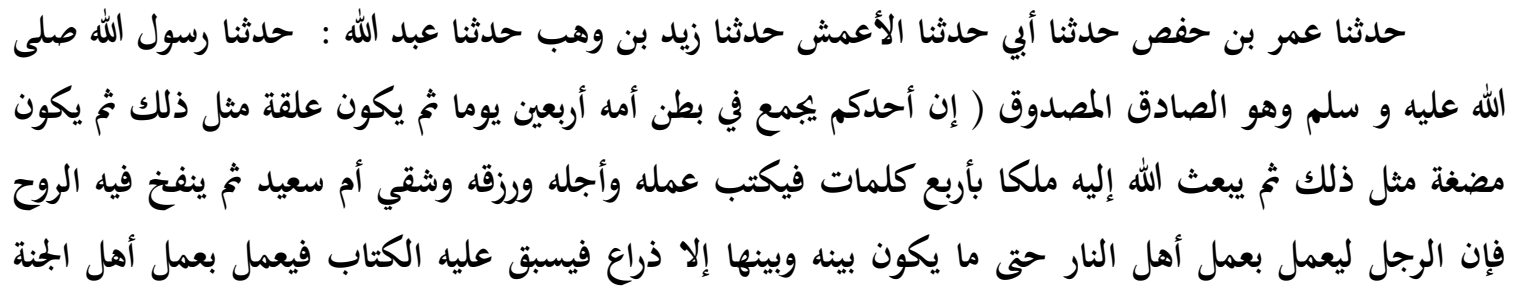

Dalam kajian ini yang menarik adalah bahwa dalam syarah hadis memng di tujukan sebgai dasar dari kelemahana Manusia, dan hal itu sangat mendasar yang kahirnya menjadi dasar kalangan Jabariyyah dalam memahami hadis secara normatif saja sehingga tidak kontektual. Ibnu Taimiyyah, Majmu Farawa Ibnu Taimiyyah (Beirut: Dar al-Fikr, 1998), h. 56. 


\section{فيدخل الجنة . وإن الرجل ليعمل بعمل أهل الجنة حتى ما يكون بينه وبينها إلا ذراع فيسبق عليه الكتاب فيعمل بعمل أهل النار فيدخل النار.}

Artinya: "Babwa Rasulullah saw pernah bersabda, Adakalanya seseorang mengerjakan amalan abli neraka padabal ia termasuk abli surge, dan adakalanya seseorang itu mengerjakan amalan abli surga padahal ia termasuk abli neraka". (HR. Shahih Bukhari).

Ketika hadis ini di komentari oleh Ibnu Taimiyyah, bahwa dalam hadis ini kebanyakan yang di gunakan oleh golongan Qadariyah dalam menyatakan bahwa Jabariyyah itu sangat normatif, dalam Kitab Ibnu Taimiyyah yaitu majmu Fatawa Ibnu Taimiyyah, sedangkan beberapa kalangan seperti Imam Syafi'i dan Imam Hanbali mengkafirkan cara yang digunakan oleh Qadariyah tersebut, lebih jauh lagi kalangan Ibnu Taimiyah menyatakan hadis ini harus di tempatkan pada konsep perbuatan baik dan perbuatan buruk, dalam kajian Ibnu Taimiyyah ada tiga pendapat, pertama, yang menyatakan bahwa perbuatan apapun memang datangnya dari Allah bukan dari yang lain, dan hal ini sudah menjadi ketetapan sebagaimana yang di yakini oleh kalangan Jabariyyah. Adapun pendapat yang kedua, adalah kalangan yang ada di tengah-tengah yang menyatakan bahwa ada campur tangan Allah dalam masalah perbuatan manusia, akan tetapi manusia adalah pemilih terakhir dari pilihannya sendiri, sedangkan kalangan yang ketiga, adalah kalangan yang menyatakan bahwa perbuatan itu adalah memang hak penuh manusia itu sendiri sehingga tidak ada campur tangan dari Allah sedikitpun sebagaimana yang di yakini oleh kalangan Qadariyah. ${ }^{24}$

Adapun hadis yang keempat adalah hadis yang diriwayatkan oleh Abdullah ibnu Amr:

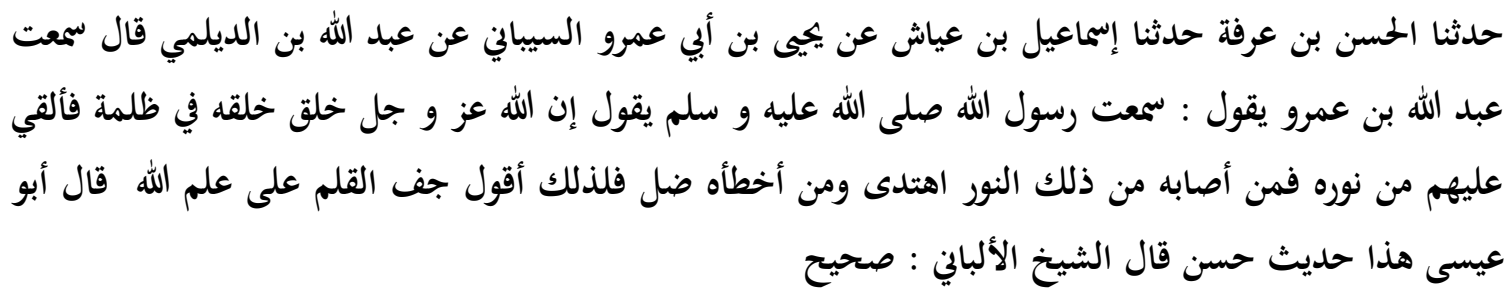

Artinya: "Babwa Rasulullah saw, pernah bersabda: Sesunggubnya Allah SWT mencipta Makbluk-Nya dalam kegelapan, lalu ia melimpabkan Nur-Nya atas mereka, maka barang siap terkena Nur-Nya maka jadilah dia orang yang memperoleh Hidayah-Nya. Dan barang siap terluput darinya, jadilah ia orang yang Sesat. Karena itu aku berkata.: "Telah Keringlab pena atas Ilmu Allab SWT". (HR At-Tirmizi.).

Hadis ini jika dilihat dari dua kitab hadis Shahih Bukahri dan Shahih Muslim terdapat keterangan yang sangat menarik, bahwa dalam syarah kedua kitab tersebut memang para ulama sangat tegas dalam melakukan kajian Hadis, kaidah yang di berikan adalah semua amal dilihat dari akhir amal tersebut, al-Amal lil al-Khawatim, amal terlihat baik dan buruk dengan melihta akhir amal tersebut, sebagian kalangan syarah hadis menjelaskan demikian. ${ }^{25}$ Sedangkan bagi kalangan Qadariyyah argument mereka lebih mengedepankan akal dan rasio sebagaimana kalangan Mutazilah maka argument yang digunakan oleh kalangan Qadariyah adalah sebagaimana yang dipahami oleh Mutazilah. Paham Qadariyah larut dalam paham Muktazilah (kaum rasionalis Islam). Muktazilah sering disebut dengan Qadariyah karena kesesuaian dalam pandangannya. Pendapatnya adalah bahwa manusia mempunyai kekuasaan secara mandiri dan merdeka tanpa keterlibatan Allah, para penganutnya meniadakan (Nafaw)

${ }^{24}$ Ibnu Taimiyyah, Majmu Fatawa Ibnu Taimiyyah. (Beirut: Dar al-Fikr, 1998), h. 256.

${ }^{25}$ Ibnu Taimiyyah, Majmu Fatawa Ibnu Taimiyyah. (Beirut: Dar al Kutub al-Ilmiayyah, 1998), h. 56. 
bahwa segala sesuatu terjadi sesuai dengan apa yang sudah di tetapkan (Qada dan Qadar) Allah. ${ }^{26}$ Dalam paham ini, keyakinan yang dibangun adalah perbuatan manusia adalah pilihannya sepenuhnya, bukan ciptaan atau pilihan Allah. Hal ini didasarkan atas kemampuan manusia dalam membedakan antara orang yang berbuat baik dan orang yang berbuat buruk dengan orang yang baik yang jelek wajahnya. Kita memuji orang yang berbuat baik karena kebaikannya, dan mencela orang yang berbuat jelek karena kejahatannya, hal demikian tidak berlaku pada orang baik atau jelek wajahnya sebagaimana pula pada orang yang tinggi atau pendek tubuhnya. Terhadap orang yang tinggi dan pendek tidak dapat dikatakan kepadanya "mengapa anda tinggi dan mengapa anda pendek", uraian tersebut kalau kita lihat dalam kasus semisal misalnya adalah terhadap orang yang berbuat lalim atau berdusta dikatakan "mengapa anda berbuat lalim atau mengapa anda berdusta", kalau sekiranya konsep lain dan dusta tidak tergantung pada kita, maka bukanlah kemestian yang membedakannya, dengan yang lain. (tinggi atau pendek), yang bergantung pada manusia adalah perbuatannya dan diadakan olehnya. ${ }^{27}$ Uraian demikian adalah sebuah penjelasan yang konkrit dari kemerdekaan perbuatan, perbuatan-perbuatan tersebut harus berakar pada maksud dan motivasinya manusia.

Dalam al-Quran misalnya tentang konsep Iradah:

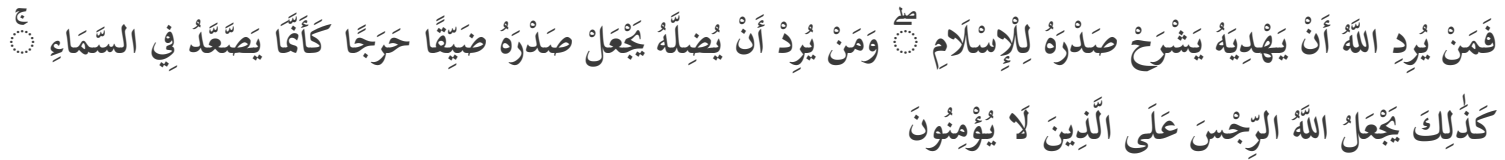

Artinya: "Barangsiapa yang Allah menghendaki akan memberikan kepadanya petunjuk, niscaya Dia melapangkan dadanya untuk (memeluk agama) Islam, dan barangsiapa yang dikehendaki Allah kesesatannya, niscaya Allab menjadikan dadanya sesak lagi sempit, seolab-olah ia sedang mendaki langit. Begitulah Allah menimpakan siksa kepada orang-orang yang tidak beriman".(QS al-An'am 6: 125).

Dalam al-Quran juga di tegaskan adanya ayat yang menjelaskan:

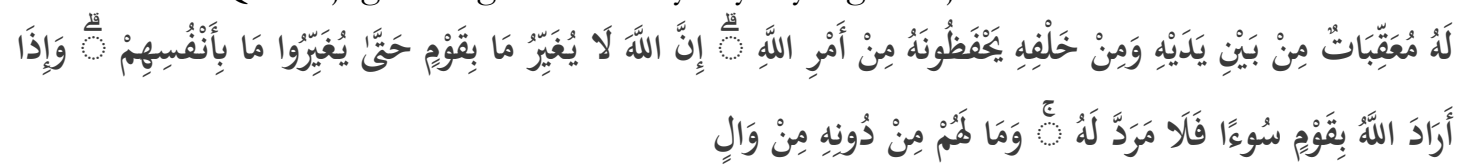

Artinya: "Bagi manusia ada malaikat-malaikat yang selalu mengikutinya bergiliran, di muka dan di belakangnya, mereka menjaganya atas perintah Allah. Sesunggubnya Allah tidak merobah Keadaan sesuatu kaum sebingga mereka merobah keadaan yang ada pada diri mereka sendiri. dan apabila Allab menghendaki keburukan terhadap sesuatu kaum, Maka tak ada yang dapat menolaknya; dan sekali-kali tak ada pelindung bagi mereka selain Dia”.(QS ar-Ra'du: 11).

Ayat ini menjelaskan bahwa manusia bebas melakukan dan berhak terhadap pilihan atas perbuatan sendiri, jika perbuatan manusia diciptakan oleh Allah mengapa manusia diberi pahala jika berbuat baik dan di siksa jika berbuat maksiat atau dosa, bukankah yang membuat atau menciptakan perbuatan itu adalah Allah SWT sendiri, jika demikian maka Allah tidak bersikap adil pada manusia, sedang manusia adalah ciptaan-Nya.

\section{Metode Pemahaman Hadis Muhammad Al-Ghazali}

Muhammad al-Ghazali adalah salah satu pemikir Islam Kontemporer yang menolak keberadan hadis-hadis yang mengajarkan amalan-amalan yang dianggap bertentangan

${ }^{26}$ Ahmad Amin, Fajr, h. 287.

${ }^{27}$ Abd Al-Jabbar Ahmad, Syarkh al-Ushul al-Khomsah, Abd al Karim Ustman (ed). (Kairo: Wahbah, 1965), h. 332. 
dengan ajaran sejati Islam. Dalam penolakan ini, dia berpegang pada metodologi pemahaman hadis yang dirumuskan dengan kitabnya an-Sunnah an-Nabawiyyah. Dalam kitab tersebut dia menekankan kritik matan hadis. Dalam kitab tersebut penekanan kritik matan hadis adalah kritik terhadap para peneliti hadis yang hanya konsep pada rangkaian periwayatan dari dan sanad dari pada kajian kritik matan dan sanad. Para peneliti hadis sebelumnya hanya berhenti pada kualitas sanad dan periwayatan dalam melihat valid atau tidaknya hadis tersebut. Dan tidak sama sekali memperhitungkan bagaimana kandungan matannya yang cacat atau tidak, seolah-olah bahwa jika perawi yang kualitasnya tinggi tidak mungkin berbuat salah. Mereka hanya terpaku pada hadis dan tidak tidak memperhatikan kandungan al-Quran. Cacat matan sebuah hadis yang di kenal mungkin tidak dianggap ada oleh mereka, karena prinsip sanad kuat hadis menjadi kuat, tetapi ditemukan oleh para ahli pikir muslim yang ahli di bidang ilmu lain misalnya ahli tafsir, ushul, kalam, fiqh, dan seterusnya. ${ }^{28}$

Lebih lanjut lagi dalam pemahaman Muhammad al-Ghazali:

Cacat yang menyertai orang-orang yang hanya menyibuk.kan diri dengan

hadis saja adalah kurangnya minat dan pengetahuan mereka untuk menukuni al-Quran dan mempelajari dengan sangat seksama, bukumbukum yang terkandung didalamnya, karean itu mengapa bertinggi bati dengan sebuah padahal kemampuan terbatas, mengapa tidak mau berlapang data dengan membiarkan orang-orang selain mereka, yang berwawasan luas, untuk menemukannya adalah illah atau keganjilan dalam beberapa hadis yang dikenal. ${ }^{29}$

Melihat realitas tersebut maka Muhammad al-Ghazali mempunyai asumsi dasar yang pada akhirnya dia bangun dalam meneliti kesahihan sebuah hadis secara matan dan sanad. Bahwa bila sebuah hadis yang matan dan perawinya kuat bisa saja mengandung cacat. Dalam kitabnya dia menulis juga "Adakalanya sebuah hadis yang sahih sanadnya tetapi lemah matannya". ${ }^{30}$ Oleh karena itu penelitian terhadap matan hadis harus tetap di galakkan sebagai upaya estafet dari para ulama-ulama hadis, upaya ini penting setelah ulama hadis melakukan seleksi ketat terhadap sanad-sanad hadis, penelitian matan hadis penting untuk memperkecil kesalahpahaman umat tentang Islam.

Untuk menyatakan cacat sebuah hadis dan matan hadis, dia menetapkan beberapa kaidah penting, pertama, al-Quran harus dijadikan dasar utama sebelum yang lainya untuk menguji validitas matan sebuah hadis. Jika ternyata kandunganya matanya tidak sesuai dan menyimpang dengan maksud nas-nas al-Quran, maka tertolaklah matan tersebut, kedua, diperlukan berbagai ilmu riwayat lainya yang bertujuan sebagai komparasi terhadap riwayat yang satu dengan yang lainya, di tinjau dari segi kuat dan lemahnya masing-masing. Ketiga, penggunan metode rasional atau Aqli, metode ini adalah mengukur masuk akal atau tidaknya suatu matan hadis. Metode ini juga dipakai untuk menarik makna-makna dan kesimpulankesimpulan dari kandungan ayat-ayat al-Quran, dari segi ini Muhammad al-Ghazali membuka pintu ruang yang lebar bagi kalangan ilmu selain pakar hadis dan ahli hadis, bagi Muhammad al-Ghazali validitas sebuah hadis adalah ruang kerja bagi interdisipliner, dan bukan monopoli ahli hadis saja. Untuk ungkapan kaidah yang pertama dan yang kedua Muhammad al-Ghazali :

Jelas bahwa untuk menetapkan sabihnya sebuah hadis dalam
segi matannya di perlukan ilmu yang mendalam tentang al-
Quran. Serta kesimpulan-kesimpulan yang dapat ditarik dari
ayat-ayatnya, baik secara langsung ataupun tidak langsung.

${ }^{28}$ Syeikh, Muhammad al-Ghazali, Studi Kritsi atas Hadis Nabi SAW: Antara Pembaman Tektulais dan Kontektual, Terjemahan Muhammad al-Baqir. (Bandung: Mizan, 1993), h.27.

${ }^{29} \mathrm{Ibid}$, h. 28.

${ }^{30} \mathrm{Ibid}$, h. 28. 
Dan ilmu tentang berbagai riwayat lainya, agar dengan itu semua Dapat di komparasikan dan di bandingkan antara satu dengan yang lainya, di tinjau dari segi kuat dan lemabnya masing-masing. ${ }^{31}$

Sedangkan untuk kaidah yang ketiga adalah, dijelaskan sebagai berikut:

Kerja sama dengan memeriksa dan menguji peninggalan Nabi Mubammad saw, sangat diperlukan, matan sebuab hadis adakalanya berkenaan dengan akidah, ibdah, muamalah, yang meliputi pengetahuan dan profesi para abli aql dan naql, (yang berdasarkan pemikiran dan penukilan) bersama-sama. Mungkin juga sebuah hadis itu berkaitan dengan dakwah, perang dan damai. Oleb sebab itu mengapa para abli di berbagai bidang yang penting dijaubkan dari segala urusan yang berkaitan dengan pengujian matan, (redaksi) yang di rawikan,? apagunanya sebuah hadis yang sanadnya sehat tetapi matannya cacat ?. ${ }^{32}$

Kerja sama tersebut menegaskan agar penentuan sahih tidaknya suatu hadis, terutama dari segi redaksinya, tidak merupakan hak monopoli bagi kalangan ahli hadis atau pakar dalam bidang hadis semata, dalam terminologi yang sederhana, perlu adanya kerja sama antara ahli hadis dan ahli keilmuan Islam lainya. ${ }^{33}$

\section{Analisis Hadis Perbuatan Manusia dalam Pandangan Jabariyah dan Qadariyah}

Hadis-hadis yang telah dielaborasi dalam kajian ini sebagaimana pembahasan sebelumnya, bahwa hadis-hadis yang digunakan oleh kalangan Jabariyah menurut para pakar hadis adalah tergolong hadis yang sahih dan sangat kuat sanad dan periwayatannya. Para pakar hadis menyatakan tidak ada masalah dalam hal sanad dan periwayatan, tetapi dalam segi matan kehujjahan hadis tersebut sangat atau masih perlu dipertanyakan, muara yang menjadikan dasar untuk mempertanyakan kehujjahan hadis tersebut dalam segi matan adalah apakah matan-matan hadis tersebut menggambarkan atau memberikan pandangan Islam mengajarkan kepada umat Islam untuk bersikap fatalistik atau Jabariyyah. Dan tidak punya sedikit ruang untuk melakukan otonom memproyeksikan dirinya menentukan masa depanya, sebgaiamana apa yang dilakukan oleh kalangan Qadariyyah.

Muhammad al-Ghazali adalah salah satu ulama hadis kontemporer yang mencoba bahkan menolak matan-matan hadis tersebut walaupun menurut para pakar hadis sebelumnya hadis ini berderajat sahih secara riwayat dan sanad yang di milikinya. Penolakan itu berdasarkan visi teoritiknya sebgaiamana pemahaman hadis sebagaimana yang telah diuraikan di atas. Ia pertama kali mengembalikan makna matan hadis kepada pemahaman alQuran, membandingkan dengan riwayat-riwayat lain untuk membandingkan tingkat kekuatan sanadnya. Dan akhirnya memberikan pemahaman rasional atas makna matan tersebut atas dasar penafsiran al-Quran oleh tidak hanya para ahli ulum al-Quran dan ahli hadis tetapi juga melibatkan profesi keahlian akademik keilmuan Islam. Dengan cara berpikir inilah kemudian menghukumi kehujjahan matan suatu hadis.

Kita lihat bagaimana Gazalian dalam mengkritik hadis-hadis tersebut, jika di lihat dari sudut pandang teori Muhammad al-Ghazali, maka hadis-hadis yang di buat argumen oleh kalangan Jabariyyah atau kalangan fatalististik, menyatakan bahwa hadis-hadis tersebut mempunyai derajat yang sangat tinggi dari haids-hadis yang sejenis, tidak bisa diterima, sebab matanya rapuh karena bertentangan dengan kandungan al-Quran. Dan tak masuk akal,

\footnotetext{
${ }^{31}$ Ibid, h. 26.

${ }^{32} \mathrm{Ibid}, \mathrm{h} .28$.

${ }^{33}$ Ibid, h. 191.
} 
banyak ayat-ayat al-Quran yang kandungannya secara ekplisit maupun implisit yang bertentangan dengan hadis tersebut di antaranya adalah:

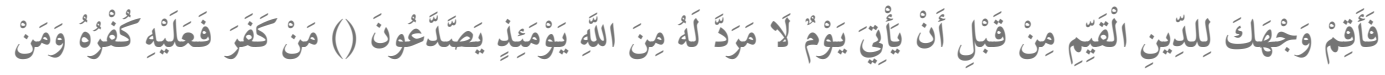

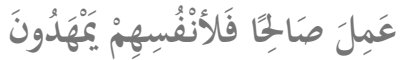

Artinya: "Oleh karena itu, hadapkanlah wajahmu kepada agama yang Lurus (Islam) sebelum datang dari Allah suatu hari yang tidak dapat ditolak (kedatangannya): pada hari itu mereka terpisahpisah. Barangsiapa yang kafir Maka Dia sendirilah yang menanggung (akibat) kekafirannya itu; dan Barangsiapa yang beramal saleh Maka untuk diri mereka sendirilah mereka menyiapkan (tempat yang menyenangkean)". (QS ar-Rum (30): 43-44).

Sedangkan pada Firman Allah yang lain:

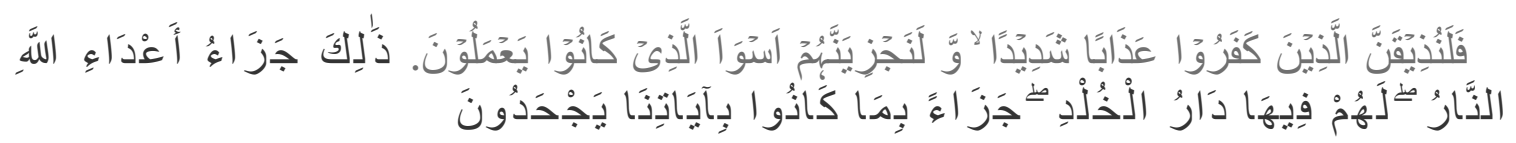

Artinya: "Maka Sesunggubnya Kami akan merasakan azab yang keras kepada orang-orang kafir dan Kami akan memberi Balasan kepada mereka dengan seburuk-buruk. pembalasan bagi apa yang telab mereka kerjakan. Demikianlah Balasan terbadap musub-musub Allah, (yaitu) neraka; mereka mendapat tempat tinggal yang kekal di dalamnya sebagai Balasan atas keingkaran mereka terbadap ayat-ayat kami”. (QS. Al-Fusshilat (41): 27-28).

Dalam firman Allah yang lain juga disebutkan dalam surah al Fushilat yang artinya: Allah berfirman: 'Lemparkanlah olehmu berdua ke dalam neraka semua orang yang sangat ingkear dan keras kepala, yang sangat menghalangi kebajikan, melanggar batas lagi ragu-ragu, yang menyembah sembahan yang lain beserta Allah Maka lemparkanlah Dia ke dalam siksaan yang sangat", yang menyertai dia, berkata (pula): "Ya Tuhan Kami, aku tidak menyesatkannya tetapi Dialah yang berada dalam kesesatan yang jauh". Allah berfirman: "Janganlah kamu bertengkar di hadapan-Ku, Padahal sesunggubnya aku dahulu telah memberikan ancaman kepadamu". Keputusan di sisi-Ku tidak dapat diubah dan aku sekali-kali tidak Menganiaya hamba-hamba-Ku". (QS al-fushilat (50): 24-29).

Dan dalam firman Allah yang lain juga disebutkan:

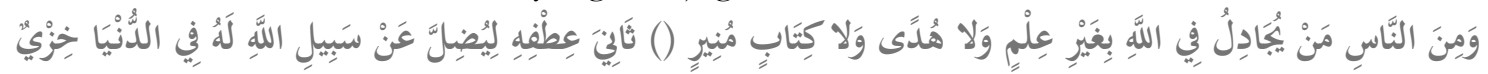

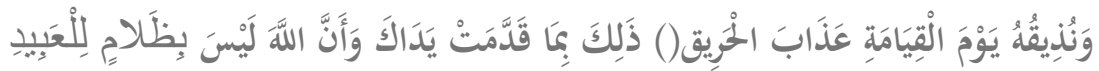

Artinya: "Dan di antara manusia ada orang-orang yang membantab tentang Allab tanpa ilmu pengetabuan, tanpa petunjuk dan tanpa kitab (wabyu) yang bercahaya [978], dengan memalingkan lambungnya, untuk menyesatkan manusia dari jalan Allah. ia mendapat kebinaan di dunia dan dibari kiamat Kami merasakan kepadanya azab neraka yang membakar. (akan dikatakan kepadanya): "Yang demikian itu, adalah disebabkan perbuatan yang dikerjakan oleh kedua tangan kamu dabulu dan Sesunggubnya Allah sekali-kali bukanlah penganiaya hamba-hamba-Nya”.(QS al-hajj (21): 8-10).

Ayat-ayat yang telah kami sebutkan diatas bahwa akibat baik dan buruk dikemudian hari yang menimpa seseorang adalah akibat perbuatan sebelumnya, dengan kata lain, hasil seseorang bergantung pada usahanya, ayat-ayat itu juga mengajarkan adanya konsep usaha dalam diri manusia dan ini berarti bahwa manusia mempunyai free will dalam bertindak. Jika dilihat secara detail dan di pahami secara tektualis maka hadis-hadis Jabariyyah atau hadishadis perbuatan manusia yang fatalistik itu akan mempengaruhi ruang kebebasan manusia. Perbuatan manusia sekan tanpa makna karena hanya melakukan hal yang telah di tentukan sebelumnya. Hal ini sangat bertentangan dengan keterangan yang terdapat dalam surat alMulk (67): 2, yang berbunyi:

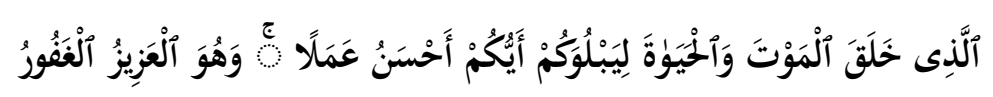

Artinya: "Yang menjadikan mati dan hidup, supaya Dia menguji kamu, siapa di antara kamu yang lebih baik amalnya. dan Dia Maba Perkasa lagi Maha Pengampun”.(QS al-Mulk (76): 2). 
Jika dilihat secara mendetail apa kritik yang di lakukan oleh Muhammad al-Ghazali hanya merujuk pada ayat al-Quran dalam membatah dan melakukan kritik terhadap hadishadis fatalis tersebut, atau hadis-hadis yang di gunakan oleh kalangan Jabariyyah. Padalah jika kita kaji secara mendalam juga di dalam al-Quran juga terdapat ayat-ayat yang secara ekplisit bisa dikatakan mendukung hadis-hadis argumen dari Jabariyyah tersebut. Misalnya adalah Firman Allah yang terdapat pada surat al-Sajdah (32): 13 yang bunyinya:

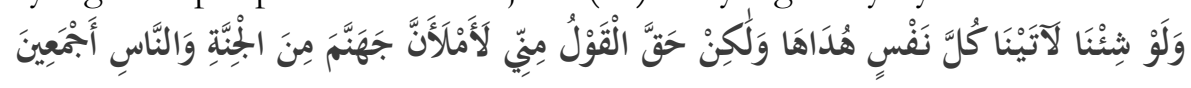

Artinya: "Dan kalau Kami menghendaki niscaya Kami akan berikan kepada tiap- tiap jiwa petunjuk, akan tetapi telah tetaplah Perkataan dari padaKu: "Sesunggubnya akan aku penubi neraka Jahannam itu dengan jin dan manusia bersama-sama". (QS al-Sajdah (32): 13).

Menanggapi persoalan tersebut menurut Muhammad al-Ghazali merespon adanya salah tafsir, dan disinilah para ahli hadis dan ahli Qur'an harus membuka diri kepada disiplindisiplin keilmuan Islam yang lainya seperti ilmu Figh, Kalam, Filsafat, Sejarah dan lain sebagainya, untuk membantu menemukan makna yang sebenarnya dari ayat tersebut, menurutnya ayat-ayat tersebut dipahami secara keliru oleh sebagian orang, sehingga menyatakan bahwa Allah, secara sewenang-wenang telah menciptakan sejumlah manusai yang menjadi penghuni neraka, dan juga menciptakan manusia yang menjadi penghuni surga. Dan Allah mendorong dengan kuat kelompok yang satu sehingga masuk neraka, dan mendorong dengan kuat kelompok lainya untuk masuk ke surga. Hal itu karena adanya kitab taqdirnya yang telah mendahuluinya. ${ }^{34}$

Menurut Muhammad al-Ghazali seharusnya memahami pertentangan hadis-hadis Jabariyyah tadi dengan kritik dari al-Quran yang mendukung adanya free wiil dengan ayat alQuran yang juga di sisi lain mendukung hadis-hadis Jabariyyah yang fatalistik, Muhammad alGhazali menyatakan demikian:

Sungguh ini adalah sebuah kedunguan, bahwa ayat-ayat tersebut mengandung arti babwa Allah itu Maha Kuasa untuk menjadikan manusia itu semuanya seperti Malaikat, yang tak akan pernab Mendurbakai Allab dalam segala Perintah-Nya dan akan selalu mengerjakan apa saja yang diperintabkan kepada mereka. Namun Ia, Tuban yang memiliki kehendak yang bebas, telab menciptakan manusia dengan acuan yang lain, yaitu yang acuan yang padannya terdapat kemampuan untuk menjadi bengkok atau lurus. Lalu ia memasukekan mereka semua dalam satu perlombaan umum, atau ujian yang bebas, maka setelah itu neraka akan dipenubi olah orang-orang yang gagal, dan surge akan dipenubi oleh orang-orang berhasil lulus. ${ }^{35}$

Jika kita berkaca pada logika Comon Sanse bahwa sifat fatalistik yang di yakini oleh kalangan Jabariyyah dengan hadis-hadis yang telah disebutkan diatas, sangat sulit untuk diterima akal sehat, sebagai sebuah ajaran dari Agama Islam. Karena apa yang diberitakan didalam hadis tersebut bahwa akan menunjukan konsekuensi bahwa manusia berusaha atau tidak barusaha adalah tidak ada bedanya, atau malahan tidak ada konsep usaha dalam diri manusia, dengan kata-katanya dia merangkum logis fatalistik seperti di bawah ini:

Anda semua telah terikat dengan takdir yang mendahului, take ada

lagi peluang untuk membebaskan diri darinya. Anda semua di

giring kearah nasib yang telab ditentukan sepenubnya atas diri

kalian, silabkan bekerja sekeras-kerasnya, namun kalian tidak

\footnotetext{
${ }^{34}$ Muhammad al-Ghazali, Studi Kritis, h. 181.

${ }^{35} \mathrm{Ibid}, \mathrm{h} 181$.
} 


\section{akan mungkin berhasil keluar dari garis yang tersuratkan, apapun usaha kalian. ${ }^{36}$}

Jika demikain maka sebenarnya bagaiamana dengan konsep atau nilai pertanggung jawaban yang harus dipikul oleh manusia kelak di hari akhir, jika kita mengikuti logika Jabariyyah atau hadis hadis yang berdimensi fatalistik maka, mestinya jika tidak ada konsep usaha maka tidak ada pula konsep pertanggung jawaban, dan usaha serta tanggung jawab itu ada pada Tuhan. Sedangkan ketika di lihat dari sudut pandang logika bahwa hadis-hadis yang digunakan oleh kalangan Jabariyyah berupa hadis-hadis fatalistik itu sulit diterima karena mengandung dua unsur kontradiktif, tetapi dipahami sama atau identik. Karena paham Jabariyyah menyatakan bahwa ketika manusia bertindak apapun tindakanya sebenarnya dia tidak bertindak karena ia tidak memiliki usaha sedikitpun dalam mementukan pilihan tindakan itu kecuali telah ditentukan Tuhan sebelumnya. Antara berusaha atau tidak berusaha, antara berkehendak atau tidak berkehendak keduanya sama saja. Secara subtansial antara keduanya jelas berbeda, ketiadaan konsep usaha ini dengan sendirinya juga menegasikan konsep pertanggung jawaban manusia karena Tuhanlah yang sebenarnya bertanggung jawab karena Dia yang telah menentukan segala sesuatu sebelumnya.

Dengan logika seperti itu, kita tidak boleh menyalahkan perilaku destruktif manusia dan sebaliknya membenarkan perilaku kontruktif manusia dan akibatnya masyarakat tidak bisa memproduksi hukum. Sebagai contoh, seorang penjahat yang pergi kesebuah ladang gandum yang telah masuk dan bulir-bulirnya penuh berisi, lalu ia menyalakan api di tengahtengahnya dan membakar semuanya, kemudian setelah ia di tangkap yang berwajib, ia mengelak dan berkata: "sesungguhnya api tidak akan menyala apabila Tuhan tidak menciptakan oksigen yang ada di udara, dan seandainya tidak ada unsur ini di udara, ladang itu tidak akan terbakar, jadi Tuhanlah yang bertanggung jawab atas dosa yang saya lakukan, karena, dengan seijin-Nyalah kejadian ini berlangsung. Dengan demikian, kandungan atau matan hadis tersebut harus di tolak atas alasan diatas, penolakan tersebut menegaskan bahwa Islam tidak mungkin mengajarkan sikap hidup yang pasrah atau Jabariyyah atau fatalistik. Hidup tetapi sebenarnya mati, Tuhan Tuhan telah menentukan rambu-rambu atau hukumhukum kehidupan, manusia secara otonom, independen dan tanpa dideterminasi berhak memilih perbuatan yang memenuhi rambu-rambu atau yang melanggarnya tetapi semua konsekuensinya akan menjadi tanggungjawabnya. Paham seperti inilah yang menungkinkan kita bisa memahami bagaimana suatu masyarakat itu bisa membangun dirinya sendiri. Demikan penolakan Muhammad al-Ghazali atas hadis-hadis Jabariyyah atau fatalistik. Diatas dari segi pemahaman rasional atau logika, dengan penjelasan rasionalitas tersebut sudah cukup bagi Muhammad al-Ghazali untuk menyatakan bahwa matan hadis diatas adalah rapuh dan tidak bisa diterima, karena tidak masuk akal.

\section{Antara Kritik dan Kontribusi Pemikiran Muhammad Al-Ghazali}

Dalam sesi ini akan dijelaskan tentang teori pemahaman hadis Muhammad al-Ghazali, dalam alenia ini akan dijelaskan apakah analisis yang di lakukan oleh Muhammad al-Ghazali dalam mevonis terhadap penolakan argumen Jabariyyah, sebagai yang juag konsen terhadap hadis penulis mencoba melihat secara fair dan seimbang teori pemahaman yang digunakan oleh Muhammad al-Ghazali. Dengan jalan demikian kita akan tahu bagaimana kontribusi pemikiran Muhammad al-Ghazali dalam studi hadis sendiri, kasus hadis Jabariyyah di sana adalah salah satu sampel yang menunjukan sanadnya kuat tetapi lemah matannya, dalam anggapan Muhammad al-Ghazali, dan dengan sampel itulah segmen kontribusi dan kritik ini penting juga di bahas.

Jika dicermati dengan kritik akademis, bahwa yang dilakukan oleh Muhammad alGhazali adalah upaya baru melakukan wacana baru dari wacana klasik, yaitu wacana superioritas sanad atau matan sebuah hadis, Muhammad al-Ghazali mencoba mengajak

${ }^{36} \mathrm{Ibid}$, h. 178. 
kediskursus baru mengenai studi hadis, yaitu lebih memperhatikan kandungan hadis untuk diteliti validitas kehujjahannya. Meminjam bahasa femenologi Husarrien, tradisi sanad "di kungkung" dulu atau dianggap sudah final, tinggal konsentrasi pada matanya bertentangan dengan al-Quran dan akal manusia yang sehat atau tidak.

Teori Muhammad al-Ghazali menyatakan untuk sampai pada matan hadis yang secara akurat, maka langkah pertama adalah mengembalikan pada kandungan makna al-Quran, langkah berikutnya yang paling mendasar adalah mengklarifikasi plausibility atau kemasukakalan kandungan makna matan hadis. Keduanya langkah yang fundamental dari teorinya ini sebenarnya adalah satu-kesatuan, Karena tidak mungkin apabila dia menerima kandungan makna al-Quran yang tidak masuk akal, atau menurutnya kandungan makna alQuran secara fundamental-esensial, adalah masuk akal atau rasional. Inilah kenapa M.Quraish Shihab dalam pengantar Buku terjemahan al-Sunnah al-Nabawiyyah bahwa kekuasan teoritik pemahaman Muhammad al-Ghazali terletak pada penyadaran tolak ukur tidak bertentangan dengan al-Quran. ${ }^{37}$

Jika dilihat dari sisi kembalinya ke al-Quran untuk menilai matan hadis, jika bertentangan denganya maka ia tertolak dan jika sebaliknya adalah maqbul maka hal tersebut bukan kontribusi baru bagi studi hadis, namun jika kita lihat bagiamana Muhammad alGhazali menggunakan al-Quran dalam menilai validitas matan hadis maka sebenarnya bisa di tangkap bahwa ia selalu melakukan rasionalisasi kandungan al-Quran. Dalam kasus hadis argument Jabariyyah diatas atau hadis-hadis yang bersifat fatalistic, terlihat dengan jelas bagaimana dia merasionalkan pemaknaan kandungan ayat ke 13 dari surat al-Sajdah untuk membuat sejalan dengan ayat-ayat lainya yang ia rujuk yang secara ekplisit maknanya bertentangan dengan matan hadis-hadis fatalistik di atas.

Oleh karena itu, kontribusi yang baru darinya adalah anjuran melakukan rasionalisasi kandungan makna al-Quran dalam langkah pertama dan utamanya dari teori mengkritik matan hadis untuk memastikan apakah sebuah hadis tersebut dari segi isinya bisa dipakai sebgai hujjah atau tidak, jadi problem pemahaman al-Qurannya adalah lebih merupakan problem rasionalisasi atau tepatnya objektivasi dari pada problem interpretasi. Barangkali inilah kontribusi beliau yang penting bagi studi hadis, memvonis validitas hadis melalui rasionalitas makna al-Quran yang membicarakan tema yang sama dengan isi atau matan tersebut. Katagori kedua, adalah bertentangan dengan akal nampaknya adalah ajang metodologis untuk memaknai al-Quran sekaligus juga matan hadisnya.

Adapun sisi kritik terhadap pemikiran Muhammad al-Ghazali adalah pada sikap mengabaikan kredibilitas periwayat terutama para Sahabat Nabi saw, dan porposi rasionalitas yang tak seimbang antara terhadap matan hadis dan kandungan al-Quran. Dua hal inilah yang akan dikemukakan di sini sebagai sikap kritis penulis atas teori Muhammad al-Ghazali tersebut, dan sekaligus untuk menegaskan bahwa setiap teori yang digagas setiap pemikir pasti mempunyai plus dan minusnya.

Fokus Muhammad al-Ghazali adalah kasus hadis yang sandnya kuat tetapi matanya dianggap sebagai sesuatu yang ekplisit dianggap atau menunjukkan cacat. Dalam kasus seperti itu, hadis itu menurut Muhammad al-Ghazali tidak dapat digunakan sebagai Hujjah. Lalu pertanyaannya adalah bagiamana kemuidan eksistensi kredibilitas para perawi dalam "rantai emas" sanad dianggap sebagai figur-figur yang adil dan jujur serta tidak mungkin melakukan manipulasi, apalagi tingkat kredibilitas Sahabat atau perawi hadis ini, menurut informasi para ulama seperti Ibn Abd Barra (w. 463). Dan al-Khatib al-Bagdadi (w.463), telah disepakati oleh ulama Islam. Imam Ibn Abd al-Barra menuturkan bahwa kita tidak perlu meneliti identitas sahabat, karena umat Islam sepakat bahwa seluruh sahabat nabi saw memiliki sifat-sifat adalab (kredibilitas). ${ }^{38}$ Sementara itu al-Khatib al-Bagdadi menyatakan bahwa pendapat yang menyatakan bahwa seluruh sahabat memiliki kridibilitas sebgai

${ }^{37}$ Ibid, h. 11.

${ }^{38}$ Ibn Abd alBarra, al-Isti'ab fi Asma al-Ashab. (Mesir: Matba'ah al-Sa'adah, 1328 H). h. 9. 
periwayat hadis adalah merupakan mazhab semua ulama, baik ulama hadis maupun ulama fiqh. $^{39}$

Konsekuensi dari pengabaian kridibilitas para perawi adalah semuanya sebuah eksistensi hadis, penulis pikir jika menemukan kasus dengan sanad kuat tetapi matan meragukan, bukan kemudian menghukuminya bahwa hadis ini pasti rapuh seperti apa yang telah di lakukan oleh Muhammad al-Ghazali, melainkan tidak secara langsung menolak hadis itu karena kita bisa mengatasi matannya dengan cara mentakwilkan dengan cara mengkaitkan dengan hadis-hadis senada, cara ini dulu barangkali yang perlu di lakukan sebelum memvonis dengan mempertentangkannya dengan al-Quran. Hal ini sekaligus masuk dalam kelemahan teorinya, mengapa Muhammad al-Ghazali hanya melakukan rasionalisasi atas makna al-Quran dan tidak pada hadis. Hadis dari segi matannya seolah-olah diterima mentah-mentah secara tektualis tanpa pentakwilan, sementara pemaknaan al-Quran di tidak demikian. Padahal apabila dilakukan rasionalitas, terlebih penakwilan atas hadis-hadis argumen Jabariyyah tersebut, maka akan bisa diperoleh pemahaman yang identik dengan ketika Muhammad al-Ghazali melakukan rasionalitas terhadap kandungan al-Quran dan asSajdah: 13 diatas, dengan demikian tidak akan terjadi pengabaian kredibiitas perawi hadis tanpa terlebih dahulu membuktikan makna matan hadis secara interpretatif.

Jika di sangkut pautkan dengan kajian sayrah hadis, maka Muhammad Al-Ghazali tidak membaca secara mendetail bagaimana sebuah hadis sebenarnya dapat di jelaskan dalam syarah hadis tersebut, pada wilayah-wilayah hadis-hadis fatalistik miliknya Jabariyyah memang jika mengacu pada kalangan ulama akan terjadi penafsiran yang tidak jauh berbeda sebagaimana dilakukan olehk kalangan Jabriyyah itu sendiri, sedangkan jika mengacu pada kalangan ulama kontemporer mereka cenderung melakukan dan menampilkan seluruh pendapat kemudian di komentari bahwa dalam hadis ini terjadi perbedaan pendapat dan terjadi banyak sekali penafsiran serta ketidakrasionalitasan.

\section{Simpulan}

Di dalam memahami hadis haruslah dengan jalan memposisikan hadis dalam satukesatuan antara sanad dan matannya, karena hadis tanpa sanad adalah bohong, dan hadis hanya matannya saja adalah nonsense, kasus hadis sanad kuat dan matan lemah, seperti yang menjadi fokus kajian dalam makalah ini yang bertemakan perbuatan manusia dalam perpekstif hadis dalam pandangan Muhammad al-Ghazali harus dilihat dengan tidak serta merta mengabaikan kredibilitas para perawi, karena masih ada peluang untuk mendamaikannya dengan jalan menafsirkan atau mentakwilkan matan tersebut terlebih dahulu. Bukan menerima matan secara tektualis tanpa usaha menafsirkan seperti terkesan dalam teori pemahaman hadis dalam pandangan Muhammad al-Ghazali.

Dalam diskurusus matan sebagai kelanjutan dari penghargaan terhadap kredibilitas perawi hadis sebaiknya dikembangkan ke wilayah hermenutika, karena kasus yang diangkat oleh Muhammad al-Ghazali berupa hadis-hadis argument kalangan Jabariyyah sebenarnya adalah masalah hermenetika bukan hanya sekedar rasionalitas. Dengan mengedepankan problem hermeneutika ini, cara mengabaikan kredibilitas perawi hadis tidak akan terjadi. Sedangkan dari sisi filosofisnya, Muhammad al-Ghazali tampak jelas sangat menolak konsep kebebasan manusia paham Jabariyyah, bahkan juga kurang setuju dengan paham asyariyyah. Jika dilihat dari interpretasi rasionalitasnya. Nampak dia condong pada paham Mutazilabnya. Karena kentalnya prinsip kausalitas dalam logika pemahamannya, yakni bahwa antara berusaha dan tidak berusaha tidak bisa dimengerti sama saja akibatnya, setiap pilihan bebas manusia membawa konsekuensi pertanggungjawaban perbuatan manusia.

Pada bagian hadis-hadis fatalistik jika dibaca dengan menggunakan kajian syarah hadis maka akan di temukan juga perdebatan yang menarik, bahwa dalam kajian tersebut kalangan ulama kontemporer lebih menyatakan berada pada konsep tengah-tengah walaupun dia

${ }^{39}$ Al-Kahatib al-bagdadi, Al-Kifayah fi Ibn al-Riwayah. (Beirut : al-Maktabah al-Ilmiah, tt), h. 49. 
condong untuk memberikan ruang kebebasan dalam menyatakan bahwa manusia mempunyai kesempatan yang banyak untuk mengatur perbuatan sendiri.

\section{Daftar Pustaka}

Amin, Ahmad, (1975). Fajr al-Islam, Kairo: An-Nahdah al-Misriyyah.

Al-Bagdadi, Al-Khatib, Al-Kifayah fi Tlm ar-Riwayah, Beirut: Al-Maktabah al-Ilmiyyah, tt. Al Barr, ibn 'Abd, (1328H). Al-Istiab fi al-Asma al Ashab, Beirut: Al-Matba'ah as-Sa'adah.

Al-Ghazali, Syaikh Muhammad, (1996). Berdialog dengan Al-Quran Memahami Pesan-Pesan Kitab Suci Dalam Kehidupan Masa Kini, penerjemah, Maskur Hakim dan Ubaidillah, Bandung, Mizan.

(1989). As-Sunnah an-nabawiyyah bain abl Fiqh wa Abl Hadis, Beirut: Dar asySyuruq. (1993). Analisis Polemik hadis Nabi SAW, Antara Pemahaman Tektual dan Kontektual Penerjemah Muhammad al-Baqir, Bandung: Mizan. ,(1997). Analisis Polemik Hadis Tranformasi Modernisasi, penerjemah, Muhammad Munawir az-Zahidi, Surabaya, Dunia Ilmu.

Al-Husaini, Ishak Musa, (1983). Ikhwan al Muslimun, Jakarta: Grafiti Press.

Nasution, Harun, (1978). Teologi, Islam, Aliran-Aliran Sejarah Analisis Perbandingan, Jakarta: Yayasan Penerbit Universitas Indonesia.

Al-Syahrastani, Muhammad 'Abd al-Karim, Al-Milal wa an-Nihal, Beirut: Dar al-Fikr, tt.

Rahman, Jallaudin, (1992). Konsep Perbuatan Manusia Menurut Al-Quran Suatu Kajian Tafsir Tematik, Jakarta: PT. Bulan Bintang.

Taimiyyah, Ibnu, (1998). Majmu Fatawa Ibnu Taimiyyah, Dar al-Fikr. 

